\title{
Shorter Antibacterial Peptide Having High Selectivity for $E$. coli Membranes and Low Potential for Inducing Resistance
}

\author{
Adriana Barreto-Santamaría ${ }^{1,2}{ }^{(D}$, Zuly Jenny Rivera ${ }^{3}\left(\mathbb{D}\right.$, Javier Eduardo García ${ }^{4}$ (D), \\ Hernando Curtidor ${ }^{5}$ (D), Manuel Elkin Patarroyo ${ }^{1,6}$, Manuel Alfonso Patarroyo ${ }^{7,8}(\mathbb{D}$ and \\ Gabriela Arévalo-Pinzón 1,7,*iD
}

1 Receptor-Ligand Department, Fundación Instituto de Inmunología de Colombia (FIDIC), Carrera 50\#26-20, Bogotá 111321, Colombia; adrianasantamaria10@gmail.com (A.B.-S.); mepatarr@gmail.com (M.E.P.)

2 Animal Science Faculty, Universidad de Ciencias Aplicadas y Ambientales (U.D.C.A.), Calle 222\#55-37, Bogotá 111166, Colombia

3 Chemistry Department, Sciences Faculty, Universidad Nacional de Colombia, Carrera 45\#26-85, Bogotá 111321, Colombia; zjriveram@unal.edu.co

4 Pharmacy Department, Sciences Faculty, Universidad Nacional de Colombia, Carrera 45\#26-85, Bogotá 111321, Colombia; jaegarciaca@unal.edu.co

5 Vicerrectoría de Investigación, Universidad ECCI, Carrera 19\#49-20, Bogotá 111311, Colombia; hercur@gmail.com

6 School of Medicine, Universidad Nacional de Colombia, Carrera 45\#26-85, Bogotá 111321, Colombia

7 School of Medicine and Health Sciences, Universidad del Rosario, Carrera 24\#63C-69, Bogotá 112111, Colombia; mapatarr.fidic@gmail.com

8 Molecular Biology and Immunology Department, Fundación Instituto de Inmunología de Colombia (FIDIC), Carrera 50\#26-20, Bogotá 111321, Colombia

* Correspondence: gabarpi@gmail.com; Tel.: +57-3244671 (ext. 145)

Received: 10 April 2020; Accepted: 13 May 2020; Published: 8 June 2020

\begin{abstract}
Antimicrobial peptides (AMPs) have been recognised as a significant therapeutic option for mitigating resistant microbial infections. It has been found recently that Plasmodium falciparum-derived, 20 residue long, peptide 35409 had antibacterial and haemolytic activity, making it an AMP having reduced selectivity, and suggesting that it should be studied more extensively for obtaining new AMPs having activity solely targeting the bacterial membrane. Peptide 35409 was thus used as template for producing short synthetic peptides ( $<20$ residues long) and evaluating their biological activity and relevant physicochemical characteristics for therapeutic use. Four of the sixteen short peptides evaluated here had activity against $E$. coli without any associated haemolytic effects. The 35409-1 derivative (17 residues long) had the best therapeutic characteristics as it had high selectivity for bacterial cells, stability in the presence of human sera, activity against $E$. coli multiresistant clinical isolates and was shorter than the original sequence. It had a powerful membranolytic effect and low potential for inducing resistance in bacteria. This peptide's characteristics highlighted its potential as an alternative for combating infection caused by E. coli multiresistant bacteria and/or for designing new AMPs.
\end{abstract}

Keywords: antimicrobial peptide; minimum inhibitory concentration (MIC); minimum bactericidal concentration (MBC); minimum haemolytic concentration (MHC); therapeutic index (TI) 


\section{Introduction}

Bacterial resistance represents a serious threat to worldwide public health; pathogens resistant to currently available antibiotics are becoming more common [1]. It is quite obvious that if suitable strategies are not introduced, then this problem will continue to grow, leading to an expected ten million deaths annually by 2050 [2]. Since it was discovered that variable length sequence (5 to 100 residues) antimicrobial peptides (AMPs) form part of almost all organisms' innate immune response [3], they have been explored and exploited as alternatives for combating microbe-related infections. This has been due to their broad spectrum of antimicrobial activity and the combination of multiple mechanisms of action and rapid activities minimising the possibility of developing resistance [4,5]. AMPs can act against bacteria, fungi, viruses, parasites and cancer cells, acting on membrane and/or anionic targets in cell wall or inside them $[5,6]$. The electrostatic interaction between AMPs' cationic amino acids (aa) and microbial membranes' negatively charged components has been proposed as crucial for AMP activity. Although AMPs may have different mechanisms of action, it is thought that their ability to act against such diverse cellular organisms is related to membrane activity [7]. Lipid bilayer disruption models have been proposed to explain such membrane activity, i.e., toroidal-pore wormhole, carpet, barrel-stave models and detergent-type membrane lytic mechanism [6,8]. For example, LL-37 and pexiganan, or MSI-78, disrupt bacterial membrane by forming a toroidal pore $[9,10]$.

Many structure-activity relationship (SAR) studies have compiled useful information about the physicochemical properties of the peptide sequences governing their activity and selectivity by microorganisms [11], such as their length, charge, structure, hydrophobicity and amphipathicity (i.e., an ability to assume an amphipathic $\alpha$-helix conformation which is intimately related to AMP activity) $[12,13]$.

Although many peptides isolated from natural sources have powerful antimicrobial activity, they frequently have certain limitations related to their toxicity against mammalian cells, high production costs and poor stability and/or bioavailability in host physiological conditions [14,15]; synthetic peptides have thus aroused interest. In addition to isolating natural AMPs [16], synthetic AMPs can be obtained by recombinant expression [17] or chemical synthesis [18]; the latter has become popular due to its advantages such as extremely pure products being able to be obtained rapidly and efficiently [19].

Many peptide candidates are currently undergoing preclinical and clinical studies [20]. However, some of them have been limited due to in vivo model results not reflecting those suggested by the promising results of in vitro studies, and even clinical trial results do not reflect preclinical studies' results in animal models [21]. Iseganan (protegrin-1 analogue) is a case in point as it failed in phase III clinical trials as a mouthwash for reducing mucositis and stomatitis (oral mucositis) in chemotherapy patients [22]. XMP.629 is another example as it failed to demonstrate its efficacy for treating acne in phase III clinical trials along with Omiganan, which failed to prevent or reduce venous catheter-related bloodstream infections [21]. This also happened with pexiganan, the first commercially developed AMP. Pexiganan is a magainin-derived peptide which had shown promising results in several studies for treating diabetic foot infections [23,24]; however, it required very high doses in an animal model to be effective and failed to demonstrate therapeutic advantages over agents available for approval by the US Food and Drug Administration (FDA) [25].

Despite such disappointing results, AMPs still hold the spotlight as new generation antibiotics due to their versatility regarding being improved by chemical synthesis. Seven AMPs have been approved by the FDA, with their half-lives ranging from $5 \mathrm{~h}$ to 14 days. Vancomycin and its derivative dalbavancin (i.e., a lipoglycopeptide) inhibit bacterial wall synthesis, while its derivatives oritavancin and telavancin have a dual membranolytic and wall synthesis inhibition mechanisms. Gramicidin D is a pore-forming linear peptide whose half-life is unknown. Daptomycin is a membranolytic, cyclic lipopeptide and colistin or polymyxin $\mathrm{E}$ is another membranolytic, cyclic lipopeptide [26].

Apart from these AMPs, the FDA has approved many more peptides for other therapeutic applications such as treating diabetes and/or cancer [26]. The related findings highlight peptide 
engineering's fundamental role in obtaining optimised sequences in laboratories, having a place in a therapeutic setting [15].

Such optimisation would include chemical synthesis, as it enables a broad range of modifications to be made to peptide design for improving therapeutic properties such as cyclisation or introducing non-natural amino acids (aa) or non-peptide portions [15,27]. Several researchers have adopted a chemical synthesis-based approach to obtaining shorter antimicrobial derivatives as this can increase selectivity and stability while reducing production costs [3]. Chemical synthesis is shown to be robust in this type of study as it enables a diversity of different length sequences to be obtained rapidly, thereby having different physicochemical characteristics [28].

A 20 aa-long P. falciparum Rifin protein-derived peptide $P f$ Rif $\left({ }^{321}\right.$ RYRRKKKMKKALQYIKLLKE $\left.{ }^{340}\right)$, also known as peptide 35409, in which lysine has been replaced by alanine in position 331, has been shown to have antibacterial activity against Escherichia coli ML35 at $22 \mu \mathrm{M}$ minimum inhibitory concentration (MIC). This peptide did not have cytotoxic activity against HeLa and HepG2 human cell lines, but did have activity against human red blood cells (hRBC) at $1.5 \mu \mathrm{M}$ minimum haemolytic concentration (MHC). Its therapeutic index (TI) calculated for E. coli ML35 is 0.045, indicating low selectivity [29], thereby restricting its therapeutic use [30]. Considering the 35409 sequence's antibacterial potential and the urgent need for developing new molecules having activity against microorganisms, this research was focused on obtaining short 35409-derived synthetic peptides having high selectivity for microorganisms. This led to selecting 16 synthetic peptides for various antibacterial and haemolytic assays. Four derivatives proving active against $E$. coli and inactive against $h R B C$ were thus identified by bioinformatics analysis, structural data and functional assays. Among them, peptide 35409-1, which adopted an $\alpha$-helical conformation in sodium dodecyl sulphate (SDS), showed the greatest antibacterial potential against ATCC strains and clinical isolates.

This study led to the obtaining of a 17 residue long sequence having a selective membranolytic effect against $E$. coli cells, stable activity in the presence of human sera and low potential for inducing bacterial resistance. Such characteristics suggested that peptide 35409-1 could be a candidate for combating multiresistant bacterial infections caused by E. coli and/or designing new AMPs.

\section{Materials and Methods}

\subsection{9-Derived Peptide Synthesis}

Short peptides derived from 35409 were obtained by solid-phase peptide synthesis (SPPS) using the Fmoc/tBu strategy [31,32]. This involved using a Rink amide resin (100 mg, $0.46 \mathrm{meq} / \mathrm{g}$ substitution). Deprotection involved removing the Fmoc group by double treatment with a 25\% 4-methylpiperidine, $1 \%$ triton $\mathrm{X}-100$ in $\mathrm{N}, \mathrm{N}$-dimethylformamide (DMF) (v/v) solution at room temperature (RT) with constant shaking (CS) for $10 \mathrm{~min}$. Following four washes with DMF, 2-isopropanol (IPA) and dichloromethane (DCM), Fmoc-aa activation and coupling reactions were carried out using carbodiimide and the modified ester strategy. N,N'-Dicyclohexylcarbodiimide (DCC) and 1-hydroxy-6-chlorobenzotriazole (6-Cl-HOBt) (1:1:1; 5 excesses regarding resin meq) were dissolved in DMF for 15 min at RT with CS. Activated aa were mixed with the resin or resin-peptide and made to react for $12 \mathrm{~h}$ with CS at RT. The solution was removed by filtration and washed twice with DMF, IPA and DCM. The deprotection and coupling reactions were monitored by Kaiser test.

The side chains were deprotected and the peptide cleaved by treating the resin-peptide with a cocktail of TFA $/ \mathrm{H}_{2} \mathrm{O} / 1$,2-ethanedithiol(EDT)/triisopropylsilane (TIPS) (92.5/2.5/2.5/2.5\% v/v) for 4-6 h at RT. EDT was added to this cocktail for controlling methionine residue oxidation [33]. The solution was filtered, and the peptide precipitated by adding cold ethyl ether. The solution was spun at $2500 \mathrm{rpm}$ for $10 \mathrm{~min}$ and the precipitate washed five times with cold ethyl ether. 


\subsection{9-Derived Peptides' Purification and Characterisation}

The products were characterised by reverse-phase, high-performance liquid chromatography (RP-HPLC) and purified by solid-phase extraction (SPE) [32]. Peptide dissolved (1 mg/mL) in solvent A $(0.05 \%$ TFA in water) was analysed on HPLC Agilent (series 1260) using a C18 column (Chromolith $4.6 \times 50 \mathrm{~mm})$ and $5 \%$ to $50 \%$ elution gradient solvent B (0.05\% TFA in acetonitrile) in solvent A. Gradient time was $8 \mathrm{~min}$ at $2 \mathrm{~mL} / \mathrm{min}$ flow rate, read at $210 \mathrm{~nm}$.

An elution gradient was designed for every peptide on a Supelclean LC-18 RP-SPE column based on its chromatographic profile. Peptides dissolved in solvent A were filtered through a $0.44 \mu \mathrm{m}$ membrane and seeded in the column. Elution involved using a step gradient with increasing concentrations of solvent B; the fractions were collected and analysed by RP-HPLC, combining the fractions having the highest chromatographic purity [34].

A Bruker Daltonics Microflex LT mass spectrometer was used for determining the peptides' mass/charge ratio by matrix-assisted laser desorption ionization-time of flight (MALDI-TOF) MS [30]. The peptide $(1 \mathrm{mg} / \mathrm{mL})$ was mixed with $1 \mathrm{mg} / \mathrm{mL} \alpha$-cyano-4-hydroxycinnamic acid in an 18:2.5 $v / v$ ratio. One microlitre of this mixture was placed on the equipment's sample plate and dried at RT. Readings were made in reflextron mode at $35-50 \%$ laser power using 200 shots.

\subsection{Bioinformatics Analysis of the Peptide Sequences}

The online APD3 antimicrobial peptide calculator and predictor (http://aps.unmc.edu/AP/) was used for predicting the sequences' physicochemical characteristics [35]. HeliQuest online software (http://heliquest.ipmc.cnrs.fr/cgi-bin/ComputParamsV2.py) was used for measuring helix amphiphilicity/hydrophobic moment [36].

\subsection{Circular Dichroism (CD)}

Circular Dichroism (CD) was used for analysing the peptides at $5 \mu \mathrm{M}$ final concentration, using a $1 \mathrm{~cm}$ optical path-length quartz cuvette in 1X PBS and 1X PBS with 10mM SDS as co-dissolvent [37-39]. A Jasco J-810 spectropolarimeter with nitrogen flow was used for obtaining the spectra, making an average of three sweeps at 260 to $190 \mathrm{~nm}$ at $20 \mathrm{~nm} / \mathrm{min}$ exploration speed and one nm bandwidth. Spectra Manager Software was used for collecting the data [40].

\subsection{Determining MIC by Broth Microdilution}

The standard broth microdilution method was used for determining the peptides' MIC [41]. Briefly, serial peptide dilutions (100 to $0.2 \mu \mathrm{M}$ concentration) were incubated in 96-well plates at $100 \mu \mathrm{L} /$ well final volume for $18 \mathrm{~h}$ at $37^{\circ} \mathrm{C}$ in a damp chamber with $\sim 5 \times 10^{5} \mathrm{CFU} / \mathrm{mL}$ bacterial inoculum (calculated from the calibration curve equation previously obtained for each strain (Figure S1)). Optical density (OD) was measured at $620 \mathrm{~nm}$ after $18 \mathrm{~h}$ on a microplate reader [41,42]. Bacteria in Müller-Hinton broth (MHB) were used as negative control. The positive controls consisted of bacteria treated with template peptide 35409 [30] and bacteria treated with antibiotics (ciprofloxacin, gentamicin, ampicillin or vancomycin according to the bacterial strain). The MIC was determined as the lowest peptide concentration at which bacterial growth was not detected.

\subsection{Bactericidal Activity}

Bactericidal activity was evaluated by sowing an aliquot of Luria Bertani agar (LBA) in the wells where no growth had been detected in the MIC assay. Following $18 \mathrm{~h}$ incubation at $37^{\circ} \mathrm{C}$, the minimum bactericidal concentration (MBC) was determined as the lowest peptide concentration which could kill $99.9 \%$ of the bacteria, i.e., no growth in the agar [42]. 


\subsection{Antibacterial Activity in the Presence of Human Sera}

The MIC was also determined by microdilution in broth for evaluating whether peptide stability and activity were affected by fresh human sera with no pre-incubation or pre-incubating the peptides with human sera for $6 \mathrm{~h}$. The first assay involved peptide dilution with fresh human sera (100\%) followed by incubation with a bacterial inoculum diluted in $\mathrm{MHB}\left(\sim 5 \times 10^{5} \mathrm{CFU} / \mathrm{mL}\right)$ for starting the MIC assay. The second assay involved peptide dilution in fresh human sera (100\%) pre-incubated for $6 \mathrm{~h}$ at $37^{\circ} \mathrm{C}$ in a humid chamber before putting them in contact with the bacterial inoculum diluted in MHB $\left(\sim 5 \times 10^{5} \mathrm{CFU} / \mathrm{mL}\right)$. The assay was incubated and read as mentioned in the microdilution section.

\subsection{Antibiotic Synergy}

The checkerboard method was used for evaluating peptide antibacterial activity in combination with antibiotics [43]. The peptides at different concentrations (1:2 dilutions from $2 \times$ MIC to $0.03 \times \mathrm{MIC})$ in absence or in combination with different antibiotics and concentrations (gentamicin or ciprofloxacin) were added to a 96-well plate. The bacterial suspension was then added at $\sim 5 \times 10^{5} \mathrm{CFU} / \mathrm{mL}$ final concentration in MHB and incubated at $37^{\circ} \mathrm{C}$ for $18 \mathrm{~h}$. Absorbance was measured at $620 \mathrm{~nm}$ and individual peptide and antibiotic MIC and combined MIC were obtained. Method 3, reported by Bonapace (2002), was used for interpreting them [44]; fractional inhibitory concentration (FIC) was calculated by dividing the MIC in combination over individual MIC. The fractional inhibitory concentration index (FICI) was then calculated as the sum of peptide FIC + antibiotic FIC. A $\leq 0.5$ FICI indicated synergy, 0.5 to $\leq 4$ FICI indifference, and $>4$ FICI antagonism [45].

\subsection{Haemolytic Activity}

A haemolytic activity assay was used for determining whether peptides acted on hRBC membrane by calculating the minimum haemolytic concentration (MHC). Briefly, $100 \mu \mathrm{L}$ serial dilutions of peptides were incubated in a 96-well plate with an equal volume of a fresh hRBC suspension at 5\% v/v in 1X PBS (200-0.39 $\mu \mathrm{M}$ final peptide concentrations). The samples were spun at $1000 \times g$ for $5 \mathrm{~min}$ after having been incubated at $37^{\circ} \mathrm{C}$ for $1 \mathrm{~h}$ and a Multiskan spectrometer (Thermo Fisher) was used for measuring $100 \mu \mathrm{L}$ supernatant absorbance at $560 \mathrm{~nm}$. Treated hRBC absorbance $0.1 \%$ Triton X-100 or $100 \%$ haemolysis was used as positive control [46].

\subsection{Scanning Electron Microscopy (SEM)}

SEM was used for evaluating the effect on E. coli ATCC 25922 cells caused by the most effective peptide derivative [47]. Briefly, $5 \times 10^{7} \mathrm{CFU} / \mathrm{mL}$ was incubated with the peptides in $1 \mathrm{X}$ PBS at $37^{\circ} \mathrm{C}$ for $1 \mathrm{~h}$. The sample was washed twice with 1X PBS and suspended in $2.5 \%$ glutaraldehyde for fixing the bacteria. The samples were dehydrated gradually using ethanol at $70 \%$ to $100 \%$ concentration. The samples were mounted on metal pins (no carbon membrane), air-dried and gold plated using a Quorum Q150R ES metaliser. Untreated bacteria were used as negative control. The samples were analysed by FEI Quanta 200 SEM at $25 \mathrm{kV}$.

\subsection{Permeabilising E. coli ML35 Internal Membrane}

The ML35 strain (constitutively producing $\beta$-galactosidase) was sown in triplicate in 96-well plates $\left(\sim 5 \times 10^{7} \mathrm{CFU} / \mathrm{mL}\right)$ in the presence of peptides at $1 \times \mathrm{MIC}$ in 1 X PBS supplemented with $1.5 \mathrm{mM}$ ortho-nitrophenyl- $\beta$-D-galactoside (ONPG) substrate at $100 \mu \mathrm{L}$ final volume for ascertaining the most effective peptide derivative on E. coli internal permeability. The plates were incubated at $37^{\circ} \mathrm{C}$ and o-nitrophenol production (yellow) was monitored every $30 \mathrm{~min}$ by spectrophotometry at $405 \mathrm{~nm}$ for $4.5 \mathrm{~h}$ [48]. Bacteria treated with cecropin P1 and bacteria treated with original peptide 35409 were used as permeabilisation positive control. Untreated bacteria and ciprofloxacin-treated bacteria were used as permeabilisation negative control. 


\subsection{Evaluating the Potential for Inducing Bacterial Resistance in E. coli ATCC 25922}

The MIC against E. coli ATCC 25922 was initially determined by microdilution in broth. After $18 \mathrm{~h}$ incubation, the bacteria treated with 0.5 peptide MIC (first well having bacterial growth detected by absorbance) were sub-cultured in MHB medium for $\sim 4 \mathrm{~h}$ at $37^{\circ} \mathrm{C}$ with constant shaking ( 250 rpm). The MIC against this subculture was then determined by micro-dilution in broth. This was repeated consecutively for 18 days to determine the development of resistance by E. coli ATCC 25922 caused by continuous peptide treatment. Ciprofloxacin- and tetracycline-treated bacteria were used as controls [49]. Two independent assays were carried out in duplicate. MIC changes were plotted for each subculture (day of assay).

\subsection{Ethics Statement}

Blood samples for obtaining human RBC and sera were obtained from healthy subjects who had provided their written informed consent for inclusion in the study, which was carried out in line with the Declaration of Helsinki guidelines. The protocol was approved by the Universidad del Rosario's Research Ethics Committee: approval code DVO005 782CV-1095.

\section{Results}

\subsection{9-Derived Sequences}

Sixteen 7- to 17-aa-long peptides derived from the 35409 sequence were designed and synthesised: seven truncated sequences from the N-terminal extreme (peptides 35409-1 a 7), five truncated sequences from the C-terminal extreme (peptides 35409-8 to 12) and four truncated sequences simultaneously from the N-terminal and C-terminal extremes (peptides 35409-13 to 16). All synthesized peptides contain an amide group at $\mathrm{C}$-terminal end $\left(-\mathrm{CONH}_{2}\right)$ (Table 1).

Table 1. 35409-derived peptides' physicochemical characteristics and antibacterial activity. The peptides' minimum inhibitory concentration (MIC), minimum bactericidal concentration (MBC) and minimum haemolytic concentration (MHC) are expressed in $\mu \mathrm{M}$.

\begin{tabular}{|c|c|c|c|c|c|c|c|}
\hline \multirow{2}{*}{ Peptide } & \multirow{2}{*}{ Sequence } & \multicolumn{3}{|c|}{$\begin{array}{c}\text { Physicochemical } \\
\text { Characteristics }\end{array}$} & \multicolumn{2}{|c|}{$\mathrm{MIC} \mathrm{MBC}^{1}$} & \multirow{2}{*}{$\mathrm{MHC}^{2}$} \\
\hline & & $\mathbf{L}$ & $\begin{array}{c}\text { Net } \\
\text { Charge }\end{array}$ & $\% \mathbf{H}$ aa & $\begin{array}{l}\text { E. coli } \\
25922\end{array}$ & $\begin{array}{c}\text { P. aeruginosa } \\
27853\end{array}$ & \\
\hline 35409 & RYRRKKKMKKALQYIKLLKE & 20 & +10 & 30 & $25 / 50$ & $>100$ & 1.56 \\
\hline 35409-1 & RKKKMKKALQYIKLLKE & 17 & +8 & 35 & $25 / 25$ & $100 / 100$ & $>200$ \\
\hline $35409-2$ & KKKMKKALQYIKLLKE & 16 & +7 & 37 & $25 / 25$ & $>100$ & $>200$ \\
\hline $35409-3$ & KKMKKALQYIKLLKE & 15 & +6 & 40 & $>100$ & $>100$ & $>200$ \\
\hline $35409-4$ & KMKKALQYIKLLKE & 14 & +5 & 42 & $100 / 100$ & $>100$ & $>200$ \\
\hline $35409-5$ & MKKALQYIKLLKE & 13 & +4 & 46 & $>100$ & $>100$ & $>200$ \\
\hline $35409-6$ & ALQYIKLLKE & 10 & +2 & 50 & $>100$ & $>100$ & $>200$ \\
\hline $35409-7$ & YIKLLKE & 7 & +2 & 42 & $>100$ & $>100$ & $>200$ \\
\hline $35409-8$ & RYRRKKKMKKALQYIKL & 17 & +10 & 29 & $>100$ & $>100$ & $>200$ \\
\hline $35409-9$ & RYRRKKKMKKALQY & 14 & +9 & 21 & $>100$ & $>100$ & $>200$ \\
\hline $35409-10$ & RYRRKKKMKKA & 11 & +9 & 18 & $>100$ & $>100$ & $>200$ \\
\hline $35409-11$ & RYRRKKKMKK & 10 & +9 & 10 & $>100$ & $>100$ & $>200$ \\
\hline $35409-12$ & RYRRKKK & 7 & +7 & 0 & $>100$ & $>100$ & $>200$ \\
\hline $35409-13$ & KKMKKALQYIKLLK & 14 & +7 & 42 & $50 / 50$ & $>100$ & $>200$ \\
\hline $35409-14$ & KKMKKALQYIKL & 12 & +6 & 41 & $>100$ & $>100$ & 100 \\
\hline $35409-15$ & RKKKMKKALQY & 11 & +7 & 27 & $>100$ & $>100$ & 200 \\
\hline $35409-16$ & KMKKALQY & 8 & +4 & 37 & $>100$ & $>100$ & $>200$ \\
\hline $\mathrm{C}+$ & ciprofloxacin MIC ( $\mu \mathrm{g} / \mathrm{mL})$ & - & - & - & 0.008 & 0.256 & - \\
\hline
\end{tabular}

L: length, $\% \mathrm{H}$ aa: percentage of hydrophobic amino acids; ${ }^{1}$ minimum inhibitory concentration and minimum bactericidal concentration; ${ }^{2}$ minimum haemolytic concentration. All synthesized peptides contain an amide group at $\mathrm{C}$-terminal end $\left(-\mathrm{CONH}_{2}\right)$, this increases the charge of the peptides by +1 . 
SPPS and RP-SPE purification led to obtaining peptides having a chromatographic purity shown in Table S1. Most peptides evaluated here had $86 \%$ to $99 \%$ purity. Mass spectra gave an m/z signal very close to that expected for the species $[\mathrm{M}+\mathrm{H}]^{+}$in all cases, thereby corroborating each molecule's identity. Figure S2 gives the results for peptide 35409-1 as an example.

\subsection{Antibacterial and Haemolytic Activity}

Antibacterial and bactericidal activity was initially evaluated by determining the peptides' MIC and MBC regarding two Gram-positive strains and two Gram-negative strains. No peptide was active against Gram-positive S. aureus ATCC 25923 and E. faecalis ATCC 29212 strains at the concentrations evaluated here $(0.2-100 \mu \mathrm{M})$ (Table 1$)$. By contrast, some 35409-derived short peptides had activity against Gram-negative bacteria (Table 1). Peptides 35409-1 (17 residues) and -2 (16 residues) were capable of inhibiting bacterial growth against $E$. coli 25922 at the same concentration as that for original peptide $(25 \mu \mathrm{M})$. Interestingly, short peptides' (greater than $200 \mu \mathrm{M} \mathrm{MHC}$ ) haemolytic activity became significantly reduced regarding original peptide $35409 \mathrm{MHC}(1.56 \mu \mathrm{M})$.

\subsection{The Peptide Sequences' Physicochemical Properties}

The APD3 database was used for bioinformatics analysis of the sequences for studying the relationship between some of the peptides' physicochemical characteristics and their biological activity. This showed that changes in peptide derivative length and charge varied from +2 to +10 and hydrophobic aa percentage from $0 \%$ to $50 \%$ (Table 1 ).

CD was used for studying secondary structure elements in 1X PBS (simulating physiological conditions) and in PBS with 10 mM SDS (mimicking bacterial surfaces' negatively charged environment), as spectral differences have been observed in these media which could have been associated with AMP activity [50-52].

All the peptides had a disordered pattern in 1X PBS. The five peptides which were active against E. coli (original peptide and 35409-1, -2, -4 and -13 derivatives) had a spectral pattern characteristic of their $\alpha$-helix structure in SDS in the 200 to $260 \mathrm{~nm}$ region, particularly regarding $\sim 208 \mathrm{~nm}$ and $\sim 222 \mathrm{~nm}$ negative signals [53]. Most inactive peptides had a structurally distorted trend in SDS, shown by a negative band between 195 and $210 \mathrm{~nm}$ [53]. Two of the 12 inactive peptides seemed to adopt a marked helical trend in SDS (peptides 35409-3 and -5) (Figure 1).

\subsection{Antibiotic Synergy}

MIC, MBC and MHC assay results led to using the checkerboard method for determining just 35409-1, -2, -4 and -13 synergic effect with two antibiotics widely used in clinical therapy: ciprofloxacin and gentamicin $[54,55]$. The results were interpreted by taking the lowest checkerboard FIC index (previously reported method 3) [44]. The FIC index gave indifference for all combinations in all cases (Table 2). 


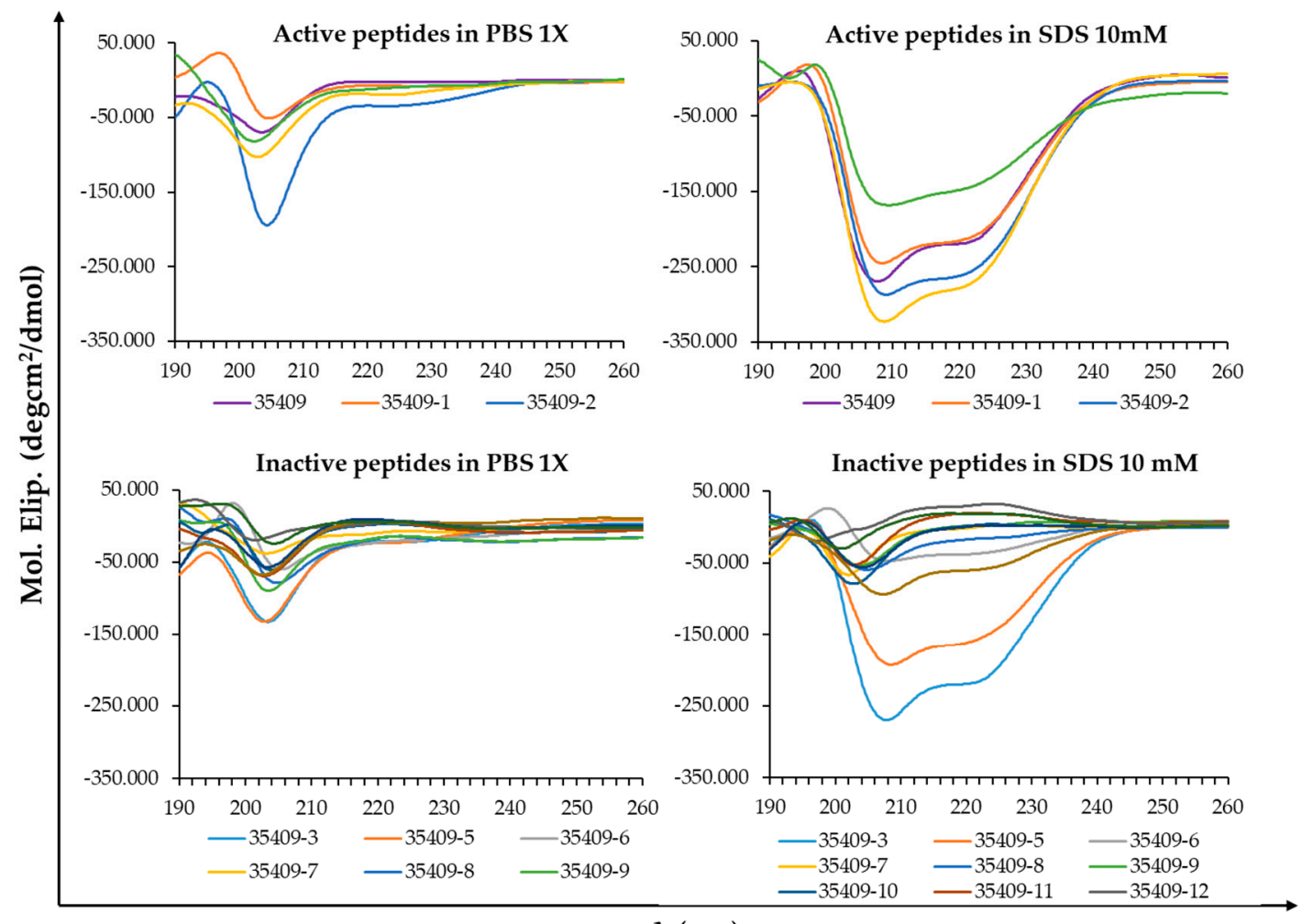

\section{$\lambda(\mathrm{nm})$}

Figure 1. Circular Dichroism (CD) spectra for original peptide 35409 and its short derivatives. Possible secondary structure elements were studied in 1X PBS and 1X PBS with $10 \mathrm{mM}$ SDS regarding peptides which were active or inactive against $E$. coli.

Table 2. Synergy with conventional antibiotics.

\begin{tabular}{|c|c|c|c|c|c|c|}
\hline \multirow[t]{2}{*}{ Antibiotic (A) } & \multirow[t]{2}{*}{ Peptide (P) } & \multicolumn{2}{|c|}{$\begin{array}{c}\text { x MIC } \\
\text { Individual/Combination }\end{array}$} & \multirow{2}{*}{$\begin{array}{c}\text { FIC } \\
P+A\end{array}$} & \multirow{2}{*}{ FIC Index } & \multirow[t]{2}{*}{ Interpretation } \\
\hline & & Peptide & Antibiotic & & & \\
\hline \multirow{4}{*}{ Ciprofloxacin } & $35409-1$ & $1 / 1$ & $1 / 2$ & $1+2$ & 3 & Indifference \\
\hline & $35409-2$ & $1 / 1$ & $1 / 2$ & $1+2$ & 3 & Indifference \\
\hline & $35409-4$ & $1 / 1$ & $1 / 2$ & $1+2$ & 3 & Indifference \\
\hline & $35409-13$ & $1 / 1$ & $1 / 2$ & $1+2$ & 3 & Indifference \\
\hline \multirow{4}{*}{ Gentamicin } & $35409-1$ & $1 / 0.25$ & $1 / 0.5$ & $0.25+0.5$ & 0.75 & Indifference \\
\hline & $35409-2$ & $1 / 0.25$ & $1 / 0.5$ & $0.25+0.5$ & 0.75 & Indifference \\
\hline & $35409-4$ & $1 / 0.25$ & $1 / 0.5$ & $0.25+0.5$ & 0.75 & Indifference \\
\hline & $35409-13$ & $1 / 0.25$ & $1 / 0.5$ & $0.25+0.5$ & 0.75 & Indifference \\
\hline
\end{tabular}

FIC: fractional inhibitory concentration. Individual ciprofloxacin MIC: $0.008 \mu \mathrm{g} / \mathrm{mL}$. Individual gentamicin MIC: $0.5 \mu \mathrm{g} / \mathrm{mL}$. Values are given in fractions regarding each individual MIC.

\subsection{Spectrum of Activity against E. coli}

The antibacterial activity of peptides $35409-1,-2,-4$ and -13 was evaluated against other ATCC strains and E. coli clinical isolates. The four peptides had activity against three out of the four ATCC strains, having 3-25 $\mu \mathrm{M}$ MIC values, including activity regarding the ampicillin-resistant ATCC 35218 strain. No peptide was active against E. coli ATCC 11775 at the concentrations evaluated here (Table 3). 
Table 3. Antibacterial activity of 35409-derived peptides against ATCC strains and E. coli clinical isolates. Peptide MIC and MBC are expressed in $\mu \mathrm{M}$.

\begin{tabular}{|c|c|c|c|c|c|c|}
\hline \multirow[b]{2}{*}{ Peptide } & \multicolumn{3}{|c|}{ MIC/MBC (ATCC Strains) } & \multicolumn{3}{|c|}{ MIC/MBC (Clinical Isolates) } \\
\hline & $\begin{array}{c}\text { E. coli ML35 } \\
43827\end{array}$ & $\begin{array}{c}\text { E. coli } \\
35218\end{array}$ & $\begin{array}{l}\text { E. coli } \\
11775\end{array}$ & $\begin{array}{c}\text { E. coli } \\
\mathrm{N}^{\circ} 4\end{array}$ & $\begin{array}{l}\text { E. coli } \\
\mathrm{N}^{\circ} 40\end{array}$ & $\begin{array}{l}\text { E. coli } \\
\mathrm{N}^{\circ} 44\end{array}$ \\
\hline 35409 & $25 / 25$ & $6 / 6$ & $>100$ & - & - & - \\
\hline $35409-1$ & $3 / 3$ & $6 / 6$ & $>100$ & $>100$ & 25 & $12.5 / 100$ \\
\hline $35409-2$ & $6 / 12.5$ & $12.5 / 25$ & $>100$ & $>100$ & 50 & $50 />100$ \\
\hline $35409-4$ & $25 / 50$ & $25 / 50$ & $>100$ & $>100$ & $>100$ & $100 />100$ \\
\hline $35409-13$ & $25 / 50$ & $25 / 100$ & $100 />100$ & $>100$ & $50 / 100$ & $25 / 50$ \\
\hline Ciprofloxacin * & 0.008 & 0.016 & 0.016 & $>0.256$ & 0.016 & $>0.256$ \\
\hline Gentamicin * & - & - & - & 2 & 1 & $>16$ \\
\hline Ampicillin * & $<0.016$ & $>16$ & $<0.016$ & - & - & - \\
\hline
\end{tabular}

${ }^{*}$ MIC in $\mu \mathrm{g} / \mathrm{mL}$.

Approximately 50 bacterial samples were then collected from E. coli-infected patients for evaluating activity of the peptides against some clinical isolates. These samples were identified and biochemically and metabolically characterised using the VITEK-2 equipment. Isolates were profiled regarding their resistance or susceptibility to a panel of conventionally used antibiotics. Three E. coli isolates having different resistance profiles were then selected following such characterisation (Appendix A):

1. Isolate 4 (from urine): extended spectrum beta-lactamase (ESBL) (-), resistant to ampicillin, quinolones and co-trimoxazole.

2. Isolate 40 (from blood): ESBL (-), resistant to ampicillin, 1st-generation cephalosporins and co-trimoxazole.

3. Isolate 44 (from blood): ESBL (+), resistant to aminoglycosides, quinolones, $\beta$-lactams (including 1st-, 3rd- and 4th-generation cephalosporins).

It was found that peptides 35409-1, -2 and -13 were active against the two clinical isolates when evaluating their MIC, isolates having a higher resistance index regarding antibiotics (isolates $\mathrm{N}^{\circ} 40$ and 44), with MICs ranging from 12.5 to $50 \mu \mathrm{M}$ (Table 3).

\subsection{Activity in the Presence of Human Sera}

Short peptide activity against E. coli ATCC 25922 was evaluated in the presence of human sera, and peptide stability was evaluated by pre-incubating the peptides with fresh human sera for $6 \mathrm{~h}$ before putting them in contact with the bacteria. No change in MIC in the presence of fresh human sera was found regarding MIC in MHB (Tables 1 and 4). Original peptide activity and that for derivatives 35409-2, -4 and -13 became lost at the concentrations evaluated here when the peptides were pre-incubated for 6 $\mathrm{h}$ in human sera, while peptide 35409-1 (17 residue-long) maintained its activity (50 $\mu \mathrm{M}$ MIC) (Table 4).

Table 4. Antibacterial activity of 35409-derived peptides in the presence of fresh human sera.

\begin{tabular}{crccc}
\hline \multirow{2}{*}{ Peptide } & Sequence & \multicolumn{3}{c}{ MIC $(\mu \mathrm{M})$ against E. coli 25922 } \\
\cline { 3 - 4 } & RYRRKKKMKKALQYIKLLKE & 25 & $\begin{array}{c}\text { Serum } \\
\text { (without Pre-Incubation) }\end{array}$ & $\begin{array}{c}\text { Serum } \\
\text { (6 h Pre-Incubation) }\end{array}$ \\
\hline $\mathbf{3 5 4 0 9}$ & MHB & 25 & $>100$ \\
$\mathbf{3 5 4 0 9 - 1}$ & RKKKMKKALQYIKLLKE & 25 & 12.5 & 50 \\
$\mathbf{3 5 4 0 9 - 2}$ & KKKMKKALQYIKLLKE & 25 & 25 & $>100$ \\
$\mathbf{3 5 4 0 9 - 4}$ & KMKKALQYIKLLKE & 100 & 100 & $>100$ \\
$\mathbf{3 5 4 0 9 - 1 3}$ & KKMKKALQYIKLLK & 50 & 50 & $>100$ \\
Ciprofloxacin * & & 0.008 & 0.008 & 0.004 \\
\hline
\end{tabular}

${ }^{*}$ MIC in $\mu \mathrm{g} / \mathrm{mL}$. 


\subsection{Mechanism of Action}

SEM was used for evaluating the effect of derivative 35409-1 on E. coli morphology. Micrographs showed damage on the surface and leaking cytoplasmatic content in treated bacteria compared to untreated bacteria (Figure 2a,b). Such results coincided with those from permeabilisation assays where peptide 35409-1 did act on E. coli internal membrane, having similar permeabilisation kinetics to those for the previously published original 20 residue-long 35409 sequence [30]. Peptide 2068, representing the cecropin P1 peptide (positive permeabilisation control), was capable of inducing a high rate of permeabilisation for the first $30 \mathrm{~min}$ of incubation, thereby coinciding with the permeabilisation kinetics and bactericidal effect previously reported for this peptide [56]. Ciprofloxacin, an antibiotic acting against topoisomerase IV and DNA gyrase [57], did not have (as expected) any significant permeabilisation effect during the time the assay lasted.

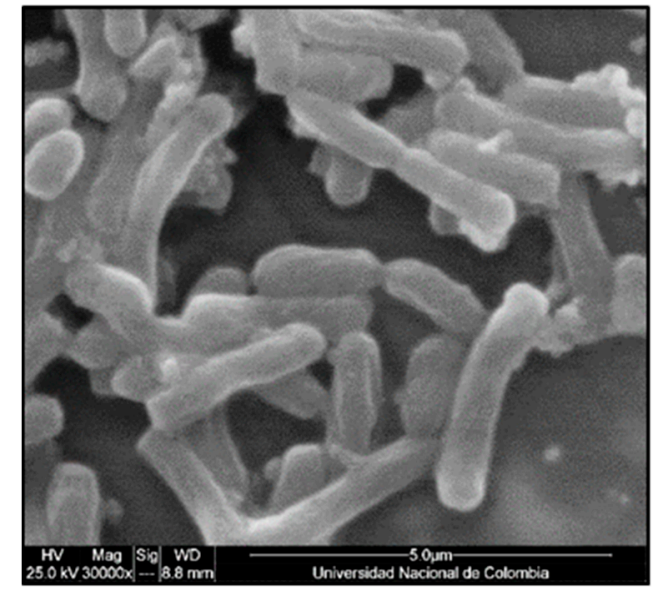

(a)

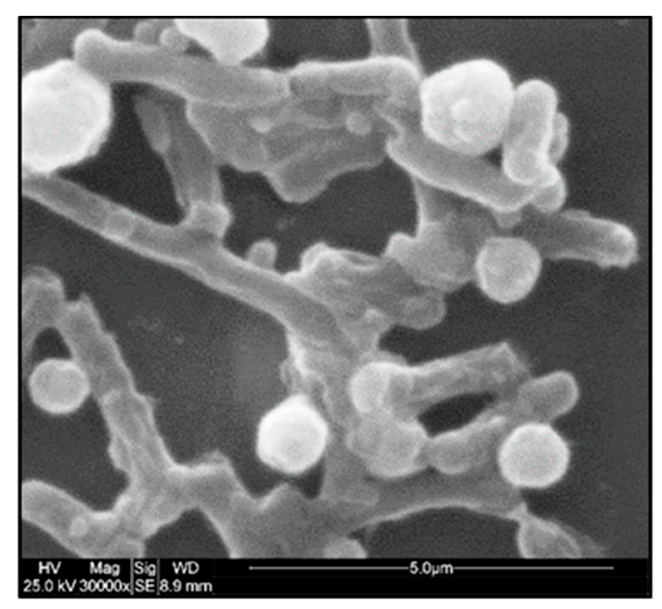

(b)

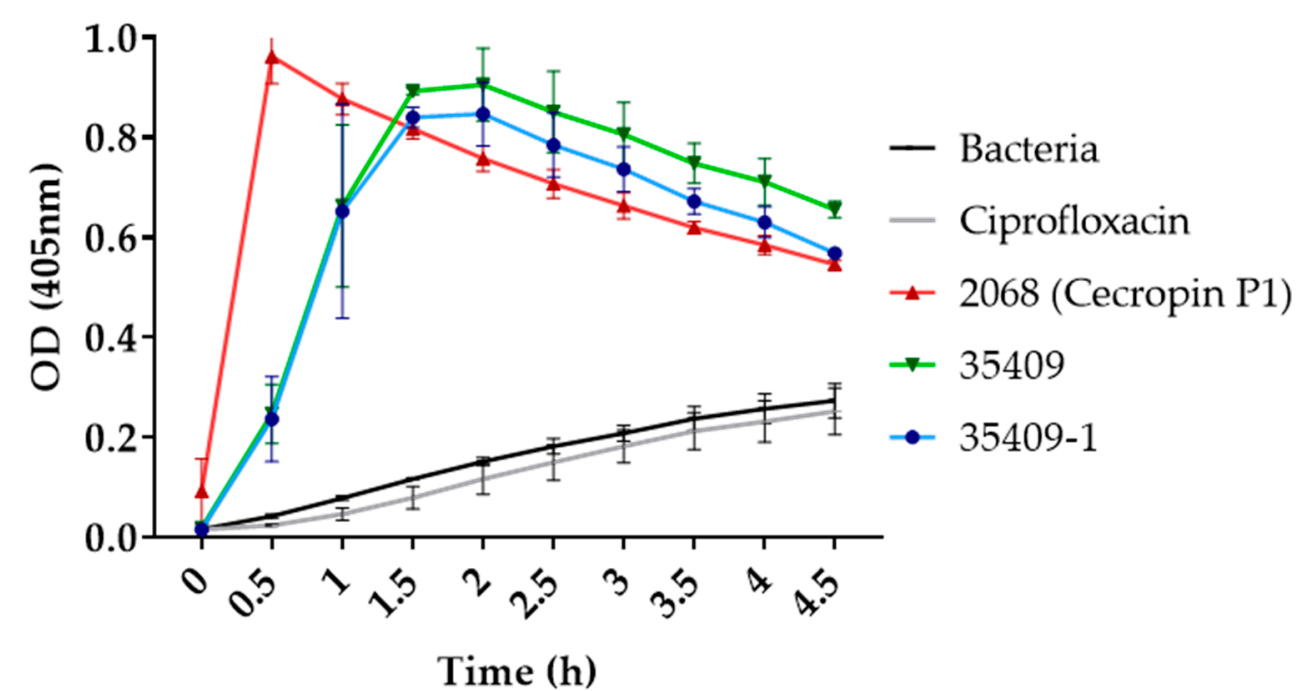

(c)

Figure 2. Peptide 35409-1 effect on E. coli membrane. Panels (a,b) show E. coli ATCC 25922, (a) without treatment and (b) treated with peptide 35409-1, by SEM. Panel (c) shows the permeabilisation of E. coli ML35 Gram-negative membrane evaluated with ONPG. The cecropin P1 peptide was used as positive permeabilisation control as it is recognised for its powerful membrane action. Untreated bacteria and ciprofloxacin-treated bacteria (an antibiotic having intracellular action) were used as negative controls. 


\subsection{Developing Resistance in E. coli ATCC 25922 Bacteria}

35409-1's potential for developing resistance was evaluated in E. coli ATCC 25922 and compared to two conventionally used antibiotics. Peptide 35409-1 had a lower MIC rate of change than that for conventional antibiotics, being capable of maintaining the same MIC for periods of up to 7-8 days in a row.

Consequently, although the antibiotics used had an up to 256-fold change in MIC after 18 days of study, 35409-1 only achieved an eight-fold increase in its MIC during the same time frame (Figure 3).

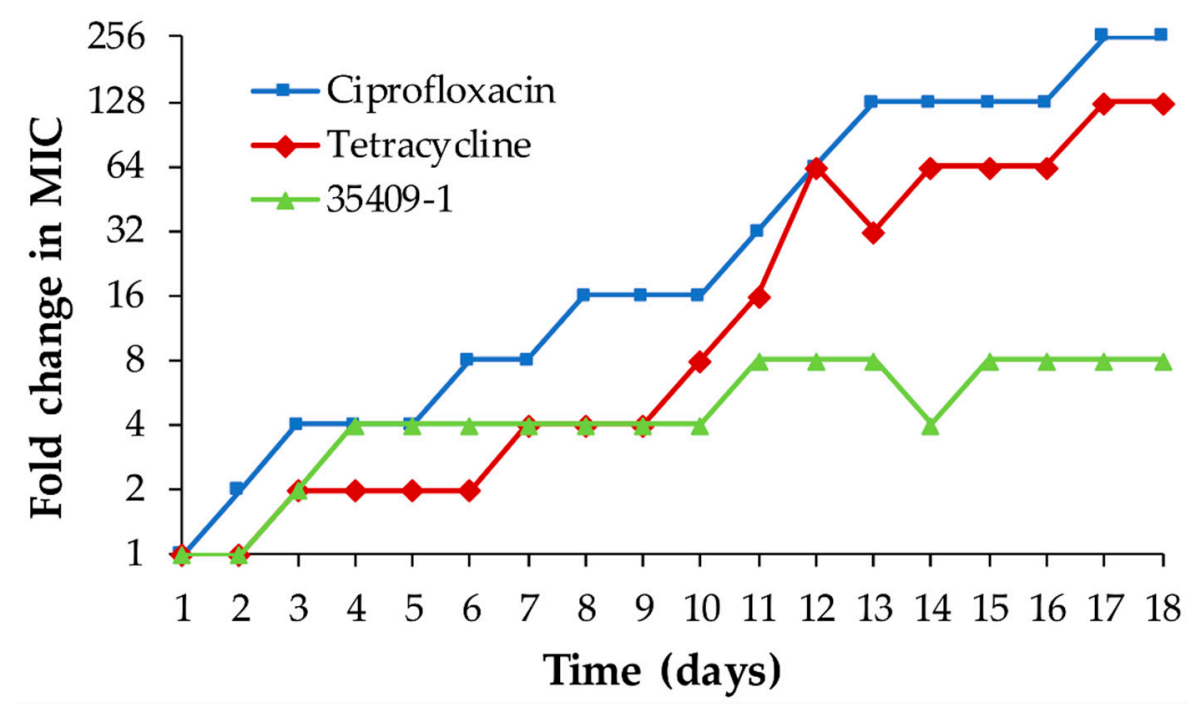

Figure 3. Developing resistance in E. coli ATCC 25922 by 35409-1-treatment. The figure shows MIC variation for bacteria repeatedly treated with $0.5 \times$ MIC for peptide 35409-1 compared to MIC variation for bacteria treated with $0.5 \times$ MIC for ciprofloxacin and tetracycline.

\section{Discussion}

AMPs represent a promising alternative for combating bacterial infections and pathogens developing resistance [58,59]. Identifying short sequences having selective antibacterial activity is thus relevant for overcoming certain limitations regarding the use of AMPs, mainly related to their synthesis, production costs and the possibility of scaling up [3]. This study has described the design and synthesis of short peptides derived from antibacterial peptide 35409 [30] and evaluated their activity against Gram-negative (E. coli and P. aeruginosa) and Gram-positive strains (S. aureus and E. faecalis). Their haemolytic activity was assessed, and the peptides characterised by bioinformatics and CD analysis. Four of the sixteen 35409-derived peptides had antibacterial activity solely targeting Gram-negative E. coli bacteria. Results for these derivatives agreed with those for the original 35409 sequence's antibacterial activity, acting against Gram-negative E. coli ML35. The original peptide 35409 displayed greater activity against liposomes having high phosphatidylethanolamine content [30], such phospholipid occurring with greater abundance in Gram-negative bacteria than Gram-positive ones [60,61]; however, this particular characteristic was not assessed here for the modified derivatives.

The derivatives had no haemolytic effect at the concentrations evaluated here, suggesting a significant increase in their selectivity for bacterial cells compared to that for the original sequence (having haemolytic activity from $1.56 \mu \mathrm{M}$ ) (Table 1). This has been reported for other sequences where short AMP derivatives have been shown to have lower lytic activity against RBCs than that of their parent peptide, on occasions having increased or reduced antibacterial activity $[62,63]$.

Peptides having 13 or less residues were seen to lose their antibacterial activity, indicating that a $\geq 35 \%$ reduction in length resulted in inactive peptides (Table 1 ). The sequences' C-terminal regions were critical for peptide action, as removing three or more residues from this extreme led to a loss of antibacterial activity. It can be appreciated that increasing charge by removing a negatively charged 
residue can confer antibacterial activity on an inactive sequence by comparing inactive peptide 35409-3 (KKMKKALQYIKLLKE) sequence to that for 35409-13 (KKMKKALQYIKLLK), which was active against E. coli ATCC 25922. Antibacterial activity results suggested that $35409 \mathrm{~N}$-terminal region RYR residues were not relevant for activity against $E$. coli strains, since derivative 35409-1 (which did not contain these three residues) had antibacterial and potential bactericidal activity against ATCC strains, similar to that for the original sequence and even more powerful against E. coli ML35 (Tables 1 and 3).

Previous reports have suggested that a reduction in AMPs' charge could reduce antibacterial activity [64]. However, peptides 35409-1 (+8) and 35409-2 (+7) maintained their antimicrobial activity despite a reduction in their charge, probably due to still being in the highest part of the range described for most AMPs ( +2 to +9$)$, thereby enabling them to become electrostatically attracted by negatively charged microbial surfaces $[64,65]$.

The CD of the peptides dissolved in 1X PBS with or without SDS was used for comparing the structural trends of peptides active against E. coli ATCC 25922 to those for inactive peptides. Previous studies have made structural comparisons of AMPs in contact with SDS micelles versus AMPs in contact with phosphatidylethanolamine (POPE)/phosphatidylglycerol (POPG) liposomes by $C D$, suggesting similar structures in both preparations. Even Nuclear Magnetic Resonance (NMR) has been used with SDS for obtaining AMP structure and as the basis for simulating AMP-membrane interactions [66,67], showing the usefulness of SDS as an initial approach in conformational studies.

CD spectra were obtained for the far ultraviolet region $(180-250 \mathrm{~nm})$ as signals in this region are very sensitive to conformational changes [68]. However, it has been argued that high chloride content in 1X PBS buffer creates noise in this region due to its strong absorption, meaning that the signal/noise ratio in some experiments is only acceptable up to $195-200 \mathrm{~nm}$ [69]. The peptides' structural trends were thus only taken into account regarding the $200-260 \mathrm{~nm}$ spectral region due to such interference. All the sequences had a disordered conformation in 1X PBS, while the original peptide and the four active derivatives (35409-1, -2, -4 and -13) had negative signals at 208 and $\sim 222 \mathrm{~nm}$ in SDS micelles (Figure 1), such signals being characteristic of an $\alpha$-helix pattern [53]. AMPs' usual pattern consists of a disordered tendency in solution and the adoption of structural tendencies defined in a membrane or solvent environment simulating it, such as SDS [51,52,70]. A helix structure is the commonest one for AMPs, suggested here for all peptides acting against E. coli; for example, an $\alpha$-helix structure is involved in $18.8 \%$ of the $41.5 \%$ of peptides having a known structure in the APD3 database (http://aps.unmc.edu/AP/statistic/statistic_structure.php). Peptide LL-37 and its short derivative KR-12-a5 provide a suitable example of such pattern as they have a disordered conformation in saline buffer and adopt an $\alpha$-helix tendency in solvents containing SDS, TFE or LPS [51]. Two of the inactive sequences had a marked $\alpha$-helix tendency, suggesting that although structural conformation is a relevant property, it is not the decisive factor for activity, and that activity and selectivity result from a set of multiple physicochemical properties as proposed by many studies [39,50,71-73].

Following initial evaluation, the study focused on short sequences having antibacterial activity, i.e., peptides $35409-1,-2,-4$ and -13 . Properties possibly being relevant for therapeutic use, such as antibiotic synergism, a spectrum of activity against other E. coli strains, activity against clinical isolates and stability in the presence of human sera, were thus evaluated. No peptide was synergistic for ciprofloxacin or gentamicin, showing that the combined administration of these antibiotics offered no therapeutic advantage; only an additive effect could be appreciated, i.e., the sum of individual activities $[43,45]$.

Peptides 35409-1, -2, -4, and -13 were active against other E. coli ATCC strains; however, none of them acted against E. coli ATCC 11775 (Serovar O1:K1:H7) (https://www.atcc.org > 11775). This could have been due to a capsular antigen, as the capsule has been proposed as a bait for AMPs, impeding their contact with bacterial membrane [74]. Peptides 35409-1, -2 and -13 acted against an ampicillin-resistant ATCC strain and two clinical multiresistant isolates (isolates 40 and 44) (Table 3 and Appendix A), thereby highlighting their clinical potential for combating bacteria having classical resistance mechanisms which have managed to overcome currently available antibiotic barriers [75,76]. Peptide 35409-1 
has an interesting MIC regarding isolate $44(12.5 \mu \mathrm{M})$ as it has been proposed that an antimicrobial must have $\mathrm{a} \leq 16 \mu \mathrm{g} / \mathrm{mL}$ or $\leq 16 \mu \mathrm{M} \mathrm{MIC}$ as a requirement for being evaluated in clinical assays [77]. Peptide 35409-1 was the derivative having greater antibacterial activity and had no haemolytic activity, unlike the original sequence. Peptide 35409-1 had less charge and was shorter than its parent peptide whilst hydrophobicity and amphipathicity were greater (Table 1 and Figure 4 ). Changes of this type are associated with reduced selectivity as generic interaction with lipid membranes is favoured [15]; however, in our case such changes led to a sequence having less haemolytic potential and similar antibacterial potential.
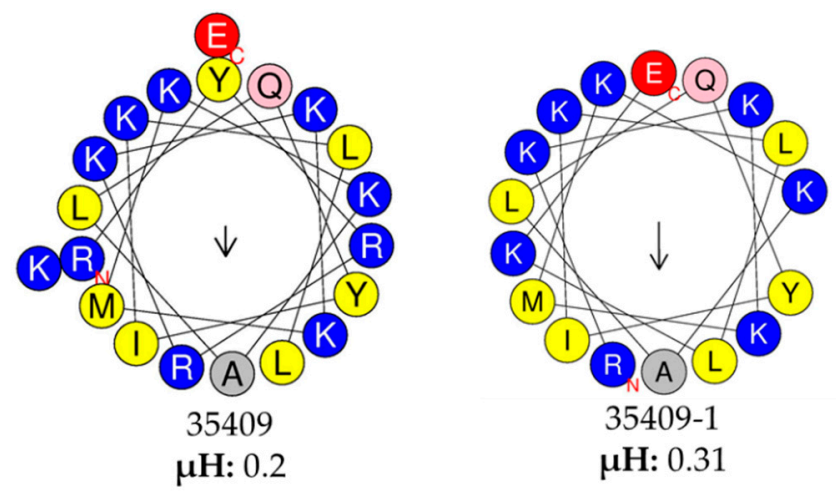

Figure 4. Helix representation and hydrophobic moment. The original peptide and peptide 35409-1 wheel projections are shown. The hydrophobic moment $(\mu \mathrm{H})$ is shown in the lower part as a measure of amphipathicity. Yellow indicates non-polar amino acids and blue indicates polar amino acids. Arrow indicates helix non-polar face proportion and direction.

The four derivatives' (35409-1, -2, -4 and -13) activity against E. coli ATCC 25922 was maintained in the presence of fresh human sera. However, when the sequences were pre-incubated with human sera for 6 h, only peptide 35409-1 conserved its activity, suggesting the molecule's greater stability in physiological conditions. This highlighted its potential use in clinical therapy as many AMPs lose their antimicrobial potential or become rapidly degraded in a targeted host and this has become one of the main limitations regarding their therapeutic use [51,78-80]. However, although human sera approaches bloodstream conditions, the residual proteases are not always representative of what occurs in the presence of RBC, where AMPs can become degraded by cytosolic proteases being released from RBC [81]. It should thus be interesting to continue evaluating 35409-1 stability in the presence of total blood and in in vivo conditions without underestimating this first in vitro approach's scope.

The original sequence (35409) and peptide 35409-1's TI were calculated by dividing the MHC by average MIC against ATCC E. coli strains. A > 17.5 TI for peptide 35409-1 indicated a significant increase in its selectivity regarding that for the original sequence as this was 220 times higher than that calculated for the original (0.08). 35409-1's marked selectivity for E. coli bacteria and activity against multiresistant strains highlighted this peptide's potential for being used as an antimicrobial. Moreover, this result led to an increase in AMPs arsenal against Gram-negative bacteria, considering that most AMPs described up to date target Gram-positive bacteria. Most AMPs are inactive against Gram-negative bacteria which could be related to lower negative charge concentration and these bacteria's greater similarity with human cell membranes $[14,15,20]$. The forgoing arouses particular interest in peptide 35409-1 for use as an AMP, even more so as E. coli has been classified by the WHO as one of the species having critical priority regarding new antimicrobial research and development due to the increasing appearance of strains which are resistant to currently available antibiotics [82].

Peptide 35409-1's possible effect on E. coli bacteria was explored by SEM. The micrographs showed that this peptide produced morphological changes on E. coli surface. Such changes involved loss of membrane continuity and intracellular material release, suggesting a membranolytic effect, the main mechanism of action described for AMPs against microorganisms [83]. Such mechanism of action 
was confirmed by using E. coli ML35 (bacteria having no lactose permease but constitutively forming $\beta$-galactosidase) and the ONPG substrate. Peptide 35409-1's permeabilisation kinetics were similar to those of the original sequence with maximum permeabilisation being reached at $1.5 \mathrm{~h}$, indicating this peptide's capability for perforating E. coli's internal membrane and coinciding with the reported bactericidal effect (Table 1). Such membrane permeabilisation action differed from antibiotics' classical mechanism of action (usually affecting specific intracellular targets or those in the wall), which could explain why peptide 35409-1 acted against bacterial isolates, which have developed resistance against many conventional antibiotics [84].

Along with the peptide's helical conformation (when using SDS), SEM and ONPG assays suggested membranolytic action. In general, AMP-membrane interactions are complex, requiring biophysical analysis. Several approaches have been used for extracting such information; isothermal titration calorimetry (ITC), bioinformatics simulations and NMR have revealed very precise information about AMP-membrane interactions [47,66,67,85-88]. For example, NMR has revealed interactions altering membrane curvature leading to its disruption for peptides such as those derived from magainin and LL-37 [9,10,88-90]. This indicated that additional studies with peptide 35409-1 are required to better understand its disposition on the membrane and the specific interactions taking place there, even though this study involved an initial approach to its mechanism of action on E. coli membrane.

AMPs' lower potential for inducing/creating antimicrobial resistance has been one of the most mentioned reasons for defending their development as alternative therapeutic agents to antibiotics [59]. This study has evaluated peptide 35409-1's potential for creating resistance regarding E. coli ATCC 25922 and compared it to that of two conventionally used antibiotics: ciprofloxacin, inhibiting topoisomerases II and IV (necessary for bacterial DNA replication, transcription, reparation and recombination) [57], and tetracycline, binding to ribosome inhibiting protein synthesis [91].

35409-1 MIC increased on the fourth day of the assay, reaching an MIC eight-fold higher than the initial reading on day 11 and maintained this until day 18. Antibiotics had a faster increase in MIC than 35409-1. Tetracycline reached an MIC 128-fold greater than its initial MIC by the end of the trial (day 18) and ciprofloxacin reached a MIC 256-fold greater than its initial MIC. This suggested that peptide 35409-1's membranolytic effect might have been associated with the microorganisms having less opportunity to create resistance against it, mainly due to its rapid and non-specific electrostatic interaction with the membrane's anionic components. This represents a high metabolic cost for microorganisms that would have to undergo a robust change in membrane composition to become resistant, instead of producing point mutations in a specific target for action [7,92]. This could be related with previous results where cationic AMPs acting on membrane did not accelerate E. coli mutation rate as occurs with antibiotics such as ciprofloxacin [93].

The results from this study have highlighted peptide 35409-1's characteristics, suggesting that it could be a promising candidate for treating multiresistant infection caused by E. coli strains. However, it is clear that there is still a long way to go and serious limitations to be overcome regarding the clinical application of a new AMP [15,94]. Further studies must thus be carried out with peptide 35409-1 for better understanding its scope and limitations; this should also improve its profile for therapeutic use from an early development stage, i.e., in the laboratory, to avoid hasty transfer to preclinical and clinical stages that may lead to another therapeutic failure [95]. Animal models must be included to demonstrate 35409-1's ability in in vivo conditions and rule out toxic effects. Even more so when it has been seen that a significant amount of AMPs called "promising" in the laboratory have then revealed their ineffectiveness when acting in in vivo models or requiring a higher than expected dose, sometimes very close to a toxic dose [23-25,94].

It is also interesting to note that 35409-1, having an average $14.3 \mu \mathrm{M}$ MIC against E. coli (ATCC strains and clinical isolates), did not induce haemolysis at 14-fold higher concentrations. This improved peptide has thus overcome early on one of the original peptide's most important limitations and that of AMPs in general, i.e., low selectivity [8,95]. It would be interesting to evaluate 35409 and 35409-1 interaction with bacterial membranes and mammalian membranes, as has been done for 
magainin 2 and its derivatives [96-98] to explore in depth whether such interaction is related to peptide 35409-1's selectivity.

\section{Conclusions}

Many studies have emphasised the need for optimising peptide sequences from early stages onward to reduce the chance of AMPs' therapeutic failure [15]. Stability, length and selectivity are characteristics to be optimised by peptide engineering $[8,25,77]$. This study has presented 17 residue long peptide 35409-1 (RKKKMKKALQYIKLLKE), an improved sequence obtained from peptide 35409, which was obtained by chemical synthesis, having 86-95\% chromatographic purity, truncating the N-terminal region. This peptide, being shorter and having less charge but greater hydrophobicity and amphipathicity than the original sequence, had antibacterial activity against E. coli and P. aeruginosa, including an ampicillin-resistant E. coli ATCC strain. This peptide sequence acted against E. coli multiresistant isolates and maintained its activity after having been pre-incubated with human sera for $6 \mathrm{~h}$. The peptide's activity seemed to be highly selective for Gram-negative E. coli bacteria as it did not act against Gram-positive ones or hRBC. Its mechanism of action was based on E. coli cytoplasmatic content leakage by bacterial membrane permeabilisation. AMP-membrane interactions have been shown to have profound implications regarding AMPs therapeutic usefulness [97,98]; five of the seven FDA-approved AMPs are active on membrane [26], so this mechanism of action must be explored in depth for 35409-1.

Peptide 35409-1 had a considerably lower potential for creating/inducing resistance than conventionally used antibiotics. These results indicated that peptide 35409-1 could be a potential candidate for use in clinical therapy or developing new, highly selective AMPs targeting Gram-negative E. coli. Its stability in the presence of sera, activity against multiresistant E. coli bacteria, and its poor potential for inducing resistance suggest its significant therapeutic advantages for confronting the current problem regarding antibacterial E. coli resistance.

Even though multiple studies are still lacking to ascertain whether improved 35409-1 could be used in the therapeutical industry [15,25], these first laboratory results have shown it to be a molecule having a good profile in vitro, removing some of AMPs' most common limitations related to their length, selectivity and stability in serum.

Supplementary Materials: The following are available online at http://www.mdpi.com/2076-2607/8/6/867/s1. Figure S1: Calibration curves used with the bacterial strains in this study and their percentage variation. Some curves were used for more than one bacterial strain, as can be seen on this figure's inset. The OD was measured in $270 \mu \mathrm{L}$ volume. Figure S2: Data regarding the synthesis, purification and characterisation of the most representative peptide from this study (peptide 35409-1). A. Summary of synthesis from the C-terminal extreme to the N-terminal extreme. B. Pure peptide chromatographic profile (HPLC). C. MALDI-TOF mass spectra, the observed signal at 2144.6 corresponds to the $[\mathrm{M}+\mathrm{H}]^{+}$specie. Table S1: RP-HPLC chromatographic characterisation of 35409 derived-peptides.

Author Contributions: Conceptualisation, A.B.-S. and H.C.; methodology, A.B.-S., Z.J.R. and J.E.G.; validation, H.C., M.E.P., M.A.P. and G.A.-P.; writing-original draft preparation, A.B.-S.; writing-review and editing, H.C., M.A.P. and G.A.-P.; funding acquisition, Z.J.R., J.E.G., M.E.P. and M.A.P. All authors have read and agreed to the published version of the manuscript.

Funding: This research was funded by the Universidad Nacional de Colombia's División de Investigación y Extensión Bogotá (DIEB), grant number 41569; the Fundación Instituto de Inmunología de Colombia (FIDIC) and the Universidad del Rosario.

Acknowledgments: We would like to thank Jason Garry for translating the manuscript and reviewing its content, as well as Xuxan Solano and Luis Escamilla for their collaboration with peptide circular dichroism.

Conflicts of Interest: The authors declare no conflict of interest. 


\section{Appendix A}

\begin{tabular}{|c|c|c|c|c|c|c|}
\hline & \multirow{2}{*}{\multicolumn{2}{|c|}{ E. coli Clinical Isolates }} & Isolate ID & 4 & 40 & 44 \\
\hline & & & Sample Origin & Urine & Blood & Blood \\
\hline \multicolumn{3}{|c|}{ Type of antibiotic } & Antibiotic & $\underset{(\mu \mathrm{g} / \mathrm{mL})}{\mathrm{MIC}}$ & $\begin{array}{c}\mathrm{MIC} \\
(\mu \mathrm{g} / \mathrm{mL})\end{array}$ & $\begin{array}{c}\text { MIC } \\
(\mu \mathrm{g} / \mathrm{mL})\end{array}$ \\
\hline \multirow{17}{*}{$\begin{array}{c}\text { Resistance } \\
\text { profile }\end{array}$} & \multirow{2}{*}{\multicolumn{2}{|c|}{ Aminoglycosides }} & Amikacin & $\leq 2(S)$ & $\leq 2(\mathrm{~S})$ & $32(\mathrm{I})$ \\
\hline & & & Gentamicin & $\leq 1(\mathrm{~S})$ & $\leq 1(\mathrm{~S})$ & $\geq 16(\mathrm{R})$ \\
\hline & $\beta$-lacta & mases & Ampicillin & $\geq 32(\mathrm{R})$ & $\geq 32(\mathrm{R})$ & $\geq 32(\mathrm{R})$ \\
\hline & $\beta$-lactam $+\beta$-lact & amase inhibitor & Ampicillin/sulbactam & $8(\mathrm{~S})$ & 16 (I) & $\geq 32(\mathrm{R})$ \\
\hline & क- & 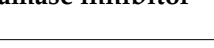 & Piperacillin/Tazobactam & $\leq 4(\mathrm{~S})$ & $\leq 4(\mathrm{~S})$ & $\geq 128$ (R) \\
\hline & & 1st-generation & Cephalothin & $4(S)$ & 16 (I) & $\geq 64(\mathrm{R})$ \\
\hline & [-lactamases & 2nd-generation & Cefoxitin & $\leq 4(S)$ & $\leq 4(\mathrm{~S})$ & $\leq 4(\mathrm{~S})$ \\
\hline & (cephalosporins) & 3rd-seneration & Cefotaxime & $\leq 1(\mathrm{~S})$ & $\leq 1(\mathrm{~S})$ & $\geq 64(\mathrm{R})$ \\
\hline & $+\beta$-lactamase & 3rd-generation & Ceftazidime & $\leq 1(\mathrm{~S})$ & $\leq 1(\mathrm{~S})$ & $\geq 64$ (R) \\
\hline & resistant & 4th-generation & Cefepime & $\leq 1(\mathrm{~S})$ & $\leq 1(\mathrm{~S})$ & $\geq 64$ (R) \\
\hline & $\beta$-lactamases & Carbanenems & Imipenem & $\leq 1(S)$ & $\leq 1(\mathrm{~S})$ & $\leq 1(\mathrm{~S})$ \\
\hline & p-Iactamases & Carodpentems & Meropenem & $\leq 0.25(\mathrm{~S})$ & $\leq 0.25(\mathrm{~S})$ & $\leq 0.25(\mathrm{~S})$ \\
\hline & \multicolumn{3}{|c|}{ ESBL } & - & - & + \\
\hline & \multirow{2}{*}{\multicolumn{2}{|c|}{ Quinolones }} & Ciprofloxacin & $\geq 4(\mathrm{R})$ & $\leq 0.25(\mathrm{~S})$ & $\geq 4(\mathrm{R})$ \\
\hline & & & Nalidixic acid & $\geq 32$ (R) & $\leq 2(\mathrm{~S})$ & $\geq 32(\mathrm{R})$ \\
\hline & \multicolumn{2}{|c|}{ Nitrofuran } & Nitrofurantoin & $\leq 16(\mathrm{~S})$ & $\leq 16(S)$ & $\leq 16(\mathrm{~S})$ \\
\hline & \multicolumn{2}{|c|}{ Co-trimoxazole } & Trimethoprim/sulfamethoxazole & $\geq 320$ (R) & $\leq 20(\mathrm{~S})$ & $\leq 20(\mathrm{~S})$ \\
\hline
\end{tabular}

\section{References}

1. WHO. Global Action Plan on Antimicrobial Resistance; WHO: Geneva, Switzerland, 2015.

2. O'Neill, J. Tackling drug-Resistant Infections Globally: Final Report and Recommendations; Review on Antimicrobial Resistance: London, UK, 2016; pp. 1-84.

3. Fjell, C.D.; Hiss, J.A.; Hancock, R.E.; Schneider, G. Designing antimicrobial peptides: Form follows function. Nat. Rev. Drug Discov. 2011, 11,37-51. [CrossRef] [PubMed]

4. Soblosky, L.; Ramamoorthy, A.; Chen, Z. Membrane interaction of antimicrobial peptides using E. coli lipid extract as model bacterial cell membranes and SFG spectroscopy. Chem Phys. Lipids 2015, 187, 20-33. [CrossRef] [PubMed]

5. Le, C.F.; Fang, C.M.; Sekaran, S.D. Intracellular Targeting Mechanisms by Antimicrobial Peptides. Antimicrob. Agents Chemother. 2017, 61. [CrossRef] [PubMed]

6. Bechinger, B.; Gorr, S.U. Antimicrobial Peptides: Mechanisms of Action and Resistance. J. Dent. Res. 2017, 96, 254-260. [CrossRef]

7. Chou, H.T.; Wen, H.W.; Kuo, T.Y.; Lin, C.C.; Chen, W.J. Interaction of cationic antimicrobial peptides with phospholipid vesicles and their antibacterial activity. Peptides 2010, 31, 1811-1820. [CrossRef]

8. Hoskin, D.W.; Ramamoorthy, A. Studies on anticancer activities of antimicrobial peptides. Biochim. Biophys. Acta 2008, 1778, 357-375. [CrossRef]

9. Ramamoorthy, A.; Thennarasu, S.; Lee, D.K.; Tan, A.; Maloy, L. Solid-state NMR investigation of the membrane-disrupting mechanism of antimicrobial peptides MSI-78 and MSI-594 derived from magainin 2 and melittin. Biophys. J. 2006, 91, 206-216. [CrossRef]

10. Henzler-Wildman, K.A.; Martinez, G.V.; Brown, M.F.; Ramamoorthy, A. Perturbation of the hydrophobic core of lipid bilayers by the human antimicrobial peptide LL-37. Biochemistry 2004, 43, 8459-8469. [CrossRef]

11. Bobone, S.; Stella, L. Selectivity of Antimicrobial Peptides: A Complex Interplay of Multiple Equilibria. Adv. Exp. Med. Biol. 2019, 1117, 175-214. [CrossRef]

12. Alfred, R.L.; Palombo, E.A.; Panozzo, J.F.; Bhave, M. The antimicrobial domains of wheat puroindolines are cell-penetrating peptides with possible intracellular mechanisms of action. PLoS ONE 2013, 8, e75488. [CrossRef] 
13. Zhang, S.K.; Song, J.W.; Gong, F.; Li, S.B.; Chang, H.Y.; Xie, H.M.; Gao, H.W.; Tan, Y.X.; Ji, S.P. Design of an alpha-helical antimicrobial peptide with improved cell-selective and potent anti-biofilm activity. Sci. Rep. 2016, 6, 27394. [CrossRef] [PubMed]

14. Fox, J.L. Antimicrobial peptides stage a comeback. Nat. Biotechnol 2013, 31, 379-382. [CrossRef] [PubMed]

15. Barreto-Santamaria, A.; Patarroyo, M.E.; Curtidor, H. Designing and optimizing new antimicrobial peptides: All targets are not the same. Crit. Rev. Clin. Lab. Sci. 2019, 56, 351-373. [CrossRef] [PubMed]

16. Diniz, L.C.L.; Miranda, A.; da Silva, P.I., Jr. Human Antimicrobial Peptide Isolated from Triatoma infestans Haemolymph, Trypanosoma cruzi-Transmitting Vector. Front. Cell Infect. Microbiol. 2018, 8, 354. [CrossRef] [PubMed]

17. Tanhaiean, A.; Azghandi, M.; Razmyar, J.; Mohammadi, E.; Sekhavati, M.H. Recombinant production of a chimeric antimicrobial peptide in E. coli and assessment of its activity against some avian clinically isolated pathogens. Microb. Pathog. 2018, 122, 73-78. [CrossRef] [PubMed]

18. Mohammed, I.; Said, D.G.; Nubile, M.; Mastropasqua, L.; Dua, H.S. Cathelicidin-Derived Synthetic Peptide Improves Therapeutic Potential of Vancomycin against Pseudomonas aeruginosa. Front. Microbiol. 2019, 10, 2190. [CrossRef]

19. Munzker, L.; Oddo, A.; Hansen, P.R. Chemical Synthesis of Antimicrobial Peptides. Methods Mol. Biol. 2017, 1548, 35-49. [CrossRef]

20. Greber, K.E.; Dawgul, M. Antimicrobial Peptides under Clinical Trials. Curr. Top. Med. Chem. 2017, 17, 620-628. [CrossRef]

21. Gordon, Y.J.; Romanowski, E.G.; McDermott, A.M. A review of antimicrobial peptides and their therapeutic potential as anti-infective drugs. Curr. Eye Res. 2005, 30, 505-515. [CrossRef]

22. Giles, F.J.; Rodriguez, R.; Weisdorf, D.; Wingard, J.R.; Martin, P.J.; Fleming, T.R.; Goldberg, S.L.; Anaissie, E.J.; Bolwell, B.J.; Chao, N.J.; et al. A phase III, randomized, double-blind, placebo-controlled, study of iseganan for the reduction of stomatitis in patients receiving stomatotoxic chemotherapy. Leuk. Res. 2004, 28, 559-565. [CrossRef]

23. Flamm, R.K.; Rhomberg, P.R.; Farrell, D.J.; Jones, R.N. In vitro spectrum of pexiganan activity; bactericidal action and resistance selection tested against pathogens with elevated MIC values to topical agents. Diagn. Microbiol. Infect. Dis. 2016, 86, 66-69. [CrossRef] [PubMed]

24. Flamm, R.K.; Rhomberg, P.R.; Simpson, K.M.; Farrell, D.J.; Sader, H.S.; Jones, R.N. In vitro spectrum of pexiganan activity when tested against pathogens from diabetic foot infections and with selected resistance mechanisms. Antimicrob. Agents Chemother. 2015, 59, 1751-1754. [CrossRef] [PubMed]

25. Gottler, L.M.; Ramamoorthy, A. Structure, membrane orientation, mechanism, and function of pexiganan-A highly potent antimicrobial peptide designed from magainin. Biochim. Biophys. Acta 2009, 1788, 1680-1686. [CrossRef] [PubMed]

26. Chen, C.H.; Lu, T.K. Development and Challenges of Antimicrobial Peptides for Therapeutic Applications. Antibiotics (Basel) 2020, 9, 24. [CrossRef] [PubMed]

27. Shao, C.; Zhu, Y.; Lai, Z.; Tan, P.; Shan, A. Antimicrobial peptides with protease stability: Progress and perspective. Future Med. Chem. 2019, 11, 2047-2050. [CrossRef] [PubMed]

28. Vishnepolsky, B.; Zaalishvili, G.; Karapetian, M.; Nasrashvili, T.; Kuljanishvili, N.; Gabrielian, A.; Rosenthal, A.; Hurt, D.E.; Tartakovsky, M.; Grigolava, M.; et al. De novo Design and in Vitro Testing of Antimicrobial Peptides against Gram-Negative Bacteria. Pharmaceuticals (Basel) 2019, 12, 82. [CrossRef]

29. Suárez, D. Evaluación y Determinación de la CMI del péptido 35409 sobre Bacterias Gram-Negativas y Gram-Positivas. Master's Thesis, Pontificia Universidad Javeriana, Bogotá, Colombia, 2012.

30. Barreto-Santamaria, A.; Curtidor, H.; Arevalo-Pinzon, G.; Herrera, C.; Suarez, D.; Perez, W.H.; Patarroyo, M.E. A New Synthetic Peptide Having Two Target of Antibacterial Action in E. coli ML35. Front. Microbiol. 2016, 7, 2006. [CrossRef]

31. Merrifield, B. Solid phase synthesis. Science 1986, 232, 341-347. [CrossRef]

32. Vergel Galeano, C.F.; Rivera Monroy, Z.J.; Rosas Pérez, J.E.; García Castañeda, J.E. Efficient synthesis of peptides with 4-methylpiperidine as Fmoc removal reagent by solid phase synthesis. J. Mex. Chem. Soc. 2014, 58, 386-392. 
33. Huang, H.; Rabenstein, D.L. A cleavage cocktail for methionine-containing peptides. J. Pept. Res. 1999, 53, 548-553. [CrossRef]

34. Insuasty Cepeda, D.S.; Pineda Castaneda, H.M.; Rodriguez Mayor, A.V.; Garcia Castaneda, J.E.; Maldonado Villamil, M.; Fierro Medina, R.; Rivera Monroy, Z.J. Synthetic Peptide Purification via Solid-Phase Extraction with Gradient Elution: A Simple, Economical, Fast, and Efficient Methodology. Molecules 2019, 24, 1215. [CrossRef] [PubMed]

35. Wang, G. Improved methods for classification, prediction, and design of antimicrobial peptides. Methods Mol. Biol. 2015, 1268, 43-66. [CrossRef] [PubMed]

36. Gautier, R.; Douguet, D.; Antonny, B.; Drin, G. HELIQUEST: A web server to screen sequences with specific alpha-helical properties. Bioinformatics 2008, 24, 2101-2102. [CrossRef] [PubMed]

37. Daleke, D.L. Regulation of phospholipid asymmetry in the erythrocyte membrane. Curr. Opin. Hematol. 2008, 15, 191-195. [CrossRef]

38. Ebenhan, T.; Gheysens, O.; Kruger, H.G.; Zeevaart, J.R.; Sathekge, M.M. Antimicrobial peptides: Their role as infection-selective tracers for molecular imaging. Biomed. Res. Int. 2014, 2014, 867381. [CrossRef] [PubMed]

39. Lee, M.Y.; Park, S.C.; Jung, M.; Shin, M.K.; Kang, H.L.; Baik, S.C.; Cheong, G.W.; Jang, M.K.; Lee, W.K. Cell-selectivity of tryptophan and tyrosine in amphiphilic alpha-helical antimicrobial peptides against drug-resistant bacteria. Biochem. Biophys. Res. Commun. 2018, 505, 478-484. [CrossRef]

40. Sitaram, N.; Chandy, M.; Pillai, V.N.; Nagaraj, R. Change of glutamic acid to lysine in a 13-residue antibacterial and hemolytic peptide results in enhanced antibacterial activity without increase in hemolytic activity. Antimicrob. Agents Chemother. 1992, 36, 2468-2472. [CrossRef]

41. Wiegand, I.; Hilpert, K.; Hancock, R.E. Agar and broth dilution methods to determine the minimal inhibitory concentration (MIC) of antimicrobial substances. Nat. Protoc. 2008, 3, 163-175. [CrossRef]

42. CLSI. Methods for Dilution Antimicrobial Susceptibility Tests for Bacteria That Grow Aerobically; Approved Standard; Clinical and Laboratory Standards Institute: Wayne, PA, USA, 2012; Volume 32.

43. Shurko, J.F.; Galega, R.S.; Li, C.; Lee, G.C. Evaluation of LL-37 antimicrobial peptide derivatives alone and in combination with vancomycin against S. aureus. J. Antibiot. (Tokyo) 2018, 71, 971-974. [CrossRef]

44. Bonapace, C.R.; Bosso, J.A.; Friedrich, L.V.; White, R.L. Comparison of methods of interpretation of checkerboard synergy testing. Diagn. Microbiol. Infect. Dis. 2002, 44, 363-366. [CrossRef]

45. Odds, F.C. Synergy, antagonism, and what the chequerboard puts between them. J. Antimicrob. Chemother. 2003, 52, 1. [CrossRef] [PubMed]

46. Joshi, S.; Bisht, G.S.; Rawat, D.S.; Kumar, A.; Kumar, R.; Maiti, S.; Pasha, S. Interaction studies of novel cell selective antimicrobial peptides with model membranes and E. coli ATCC 11775. Biochim. Biophys. Acta 2010, 1798, 1864-1875. [CrossRef] [PubMed]

47. Hartmann, M.; Berditsch, M.; Hawecker, J.; Ardakani, M.F.; Gerthsen, D.; Ulrich, A.S. Damage of the bacterial cell envelope by antimicrobial peptides gramicidin $\mathrm{S}$ and PGLa as revealed by transmission and scanning electron microscopy. Antimicrob. Agents Chemother. 2010, 54, 3132-3142. [CrossRef] [PubMed]

48. Qu, P.; Gao, W.; Chen, H.; Li, D.; Yang, N.; Zhu, J.; Feng, X.; Liu, C.; Li, Z. The Central Hinge Link Truncation of the Antimicrobial Peptide Fowlicidin-3 Enhances Its Cell Selectivity without Antibacterial Activity Loss. Antimicrob. Agents Chemother. 2016, 60, 2798-2806. [CrossRef] [PubMed]

49. Chou, S.; Wang, J.; Shang, L.; Akhtar, M.U.; Wang, Z.; Shi, B.; Feng, X.; Shan, A. Short, symmetric-helical peptides have narrow-spectrum activity with low resistance potential and high selectivity. Biomater. Sci. 2019, 7, 2394-2409. [CrossRef]

50. Wang, G. Structures of human host defense cathelicidin LL-37 and its smallest antimicrobial peptide KR-12 in lipid micelles. J. Biol. Chem. 2008, 283, 32637-32643. [CrossRef]

51. Kim, E.Y.; Rajasekaran, G.; Shin, S.Y. LL-37-derived short antimicrobial peptide KR-12-a5 and its d-amino acid substituted analogs with cell selectivity, anti-biofilm activity, synergistic effect with conventional antibiotics, and anti-inflammatory activity. Eur. J. Med. Chem. 2017, 136, 428-441. [CrossRef]

52. Jin, L.; Bai, X.; Luan, N.; Yao, H.; Zhang, Z.; Liu, W.; Chen, Y.; Yan, X.; Rong, M.; Lai, R.; et al. A Designed Tryptophan- and Lysine/Arginine-Rich Antimicrobial Peptide with Therapeutic Potential for Clinical Antibiotic-Resistant Candida albicans Vaginitis. J. Med. Chem. 2016, 59, 1791-1799. [CrossRef] 
53. Juban, M.M.; Barkley, M.D. Circular Dichroism Studies of Secondary Structure of Peptides. In Antibacterial Peptide Protocols. Methods In Molecular Biology; Shafer, W.M., Ed.; Humana Press: Totowa, NJ, USA, 1997; Volume 78.

54. De la Fuente-Salcido, N.M.; Villarreal-Prieto, J.M.; Díaz León, M.Á.; García Pérez, A.P. Evaluación de la actividad de los agentes antimicrobianos ante el desafío de la resistencia bacteriana. Rev. Mex. Cienc. Farm. $2015,46,7-16$.

55. Umerska, A.; Cassisa, V.; Bastiat, G.; Matougui, N.; Nehme, H.; Manero, F.; Eveillard, M.; Saulnier, P. Synergistic interactions between antimicrobial peptides derived from plectasin and lipid nanocapsules containing monolaurin as a cosurfactant against Staphylococcus aureus. Int. J. Nanomed. 2017, 12, 5687-5699. [CrossRef]

56. Arcidiacono, S.; Soares, J.W.; Meehan, A.M.; Marek, P.; Kirby, R. Membrane permeability and antimicrobial kinetics of cecropin P1 against Escherichia coli. J. Pept. Sci. 2009, 15, 398-403. [CrossRef] [PubMed]

57. FDA. Drug Approval Package. Available online: https://www.accessdata.fda.gov/drugsatfda_docs/nda/2004/ 019537s49_19847s27_19857s31_20780s13TOC.cfm (accessed on 28 May 2020).

58. Ageitos, J.M.; Sanchez-Perez, A.; Calo-Mata, P.; Villa, T.G. Antimicrobial peptides (AMPs): Ancient compounds that represent novel weapons in the fight against bacteria. Biochem. Pharm. 2017, 133, 117-138. [CrossRef] [PubMed]

59. Spohn, R.; Daruka, L.; Lazar, V.; Martins, A.; Vidovics, F.; Grezal, G.; Mehi, O.; Kintses, B.; Szamel, M.; Jangir, P.K.; et al. Integrated evolutionary analysis reveals antimicrobial peptides with limited resistance. Nat. Commun. 2019, 10, 4538. [CrossRef] [PubMed]

60. Epand, R.F.; Savage, P.B.; Epand, R.M. Bacterial lipid composition and the antimicrobial efficacy of cationic steroid compounds (Ceragenins). Biochim. Biophys. Acta 2007, 1768, 2500-2509. [CrossRef]

61. Zawadzka, K.; Bernat, P.; Felczak, A.; Rozalska, S.; Lisowska, K. Antibacterial activity of high concentrations of carvedilol against Gram-positive and Gram-negative bacteria. Int. J. Antimicrob. Agents 2018, 51, 458-467. [CrossRef]

62. Park, Y.; Park, S.C.; Park, H.K.; Shin, S.Y.; Kim, Y.; Hahm, K.S. Structure-activity relationship of HP (2-20) analog peptide: Enhanced antimicrobial activity by $\mathrm{N}$-terminal random coil region deletion. Biopolymers 2007, 88, 199-207. [CrossRef]

63. Subbalakshmi, C.; Nagaraj, R.; Sitaram, N. Biological activities of C-terminal 15-residue synthetic fragment of melittin: Design of an analog with improved antibacterial activity. FEBS Lett. 1999, 448, 62-66. [CrossRef]

64. Ueno, S.; Minaba, M.; Nishiuchi, Y.; Taichi, M.; Tamada, Y.; Yamazaki, T.; Kato, Y. Generation of novel cationic antimicrobial peptides from natural non-antimicrobial sequences by acid-amide substitution. Ann. Clin. Microbiol. Antimicrob. 2011, 10, 11. [CrossRef]

65. Mulder, K.C.; Lima, L.A.; Miranda, V.J.; Dias, S.C.; Franco, O.L. Current scenario of peptide-based drugs: The key roles of cationic antitumor and antiviral peptides. Front. Microbiol 2013, 4, 321. [CrossRef]

66. Agadi, N.; Vasudevan, S.; Kumar, A. Structural insight into the mechanism of action of antimicrobial peptide BMAP-28 (1-18) and its analogue mutBMAP18. J. Struct. Biol. 2018, 204, 435-448. [CrossRef]

67. Jordan, J.; Easton, P.; Hinton, J. Effects of phenylalanine substitutions in gramicidin A on the kinetics of channel formation in vesicles and channel structure in SDS micelles. Biophys. J. 2005, 88, 224-234. [CrossRef] [PubMed]

68. Sreerama, N.; Woody, R.W. Estimation of protein secondary structure from circular dichroism spectra: Comparison of CONTIN, SELCON, and CDSSTR methods with an expanded reference set. Anal. Biochem. 2000, 287, 252-260. [CrossRef] [PubMed]

69. Larsen, A.N.; Sorensen, K.K.; Johansen, N.T.; Martel, A.; Kirkensgaard, J.J.; Jensen, K.J.; Arleth, L.; Midtgaard, S.R. Dimeric peptides with three different linkers self-assemble with phospholipids to form peptide nanodiscs that stabilize membrane proteins. Soft Matter 2016, 12, 5937-5949. [CrossRef]

70. Kim, J.S.; Jeong, J.H.; Kim, Y. Design, characterization, and antimicrobial activity of a novel antimicrobial peptide derived from bovine lactophoricin. J. Microbiol. Biotechnol. 2017, 27, 759-767. [CrossRef] [PubMed]

71. Chen, Y.; Mant, C.T.; Farmer, S.W.; Hancock, R.E.; Vasil, M.L.; Hodges, R.S. Rational design of alpha-helical antimicrobial peptides with enhanced activities and specificity/therapeutic index. J. Biol. Chem. 2005, 280, 12316-12329. [CrossRef] 
72. Huang, Y.; Huang, J.; Chen, Y. Alpha-helical cationic antimicrobial peptides: Relationships of structure and function. Protein Cell 2010, 1, 143-152. [CrossRef]

73. Zelezetsky, I.; Tossi, A. Alpha-helical antimicrobial peptides-Using a sequence template to guide structure-activity relationship studies. Biochim. Biophys. Acta 2006, 1758, 1436-1449. [CrossRef]

74. Llobet, E.; Tomas, J.M.; Bengoechea, J.A. Capsule polysaccharide is a bacterial decoy for antimicrobial peptides. Microbiology 2008, 154, 3877-3886. [CrossRef]

75. Kapoor, G.; Saigal, S.; Elongavan, A. Action and resistance mechanisms of antibiotics: A guide for clinicians. J. Anaesthesiol. Clin. Pharm. 2017, 33, 300-305. [CrossRef]

76. Yeaman, M.R.; Yount, N.Y. Mechanisms of antimicrobial peptide action and resistance. Pharm. Rev. 2003, 55, 27-55. [CrossRef] [PubMed]

77. Ramesh, S.; Govender, T.; Kruger, H.G.; de la Torre, B.G.; Albericio, F. Short AntiMicrobial Peptides (SAMPs) as a class of extraordinary promising therapeutic agents. J. Pept. Sci. 2016, 22, 438-451. [CrossRef] [PubMed]

78. Bottger, R.; Hoffmann, R.; Knappe, D. Differential stability of therapeutic peptides with different proteolytic cleavage sites in blood, plasma and serum. PLoS ONE 2017, 12, e0178943. [CrossRef] [PubMed]

79. Nguyen, L.T.; Chau, J.K.; Perry, N.A.; de Boer, L.; Zaat, S.A.; Vogel, H.J. Serum stabilities of short tryptophanand arginine-rich antimicrobial peptide analogs. PLoS ONE 2010, 5. [CrossRef]

80. Knappe, D.; Henklein, P.; Hoffmann, R.; Hilpert, K. Easy strategy to protect antimicrobial peptides from fast degradation in serum. Antimicrob. Agents Chemother. 2010, 54, 4003-4005. [CrossRef]

81. Starr, C.G.; Wimley, W.C. Antimicrobial peptides are degraded by the cytosolic proteases of human erythrocytes. Biochim. Biophys. Acta Biomembr. 2017, 1859, 2319-2326. [CrossRef]

82. WHO. Global Priority List of Antibiotic-Resistant Bacteria to Guide Research, Discovery, and Development of New Antibiotics; WHO: Geneva, Switzerland, 2017.

83. Lee, T.H.; Hall, K.N.; Aguilar, M.I. Antimicrobial Peptide Structure and Mechanism of Action: A Focus on the Role of Membrane Structure. Curr. Top. Med. Chem. 2016, 16, 25-39. [CrossRef]

84. Mwangi, J.; Hao, X.; Lai, R.; Zhang, Z.Y. Antimicrobial peptides: New hope in the war against multidrug resistance. Zool. Res. 2019, 40, 488-505. [CrossRef]

85. Sun, D.; Peyear, T.A.; Bennett, W.D.; Andersen, O.S.; Lightstone, F.C.; Ingólfsson, H.I. Molecular mechanism for gramicidin dimerization and dissociation in bilayers of different thickness. Biophys. J. 2019, 117, 1831-1844. [CrossRef]

86. Thennarasu, S.; Lee, D.K.; Tan, A.; Prasad Kari, U.; Ramamoorthy, A. Antimicrobial activity and membrane selective interactions of a synthetic lipopeptide MSI-843. Biochim. Biophys. Acta 2005, 1711, 49-58. [CrossRef]

87. Thennarasu, S.; Huang, R.; Lee, D.K.; Yang, P.; Maloy, L.; Chen, Z.; Ramamoorthy, A. Limiting an antimicrobial peptide to the lipid-water interface enhances its bacterial membrane selectivity: A case study of MSI-367. Biochemistry 2010, 49, 10595-10605. [CrossRef]

88. Kamysz, E.; Sikorska, E.; Jaskiewicz, M.; Bauer, M.; Neubauer, D.; Bartoszewska, S.; Baranska-Rybak, W.; Kamysz, W. Lipidated Analogs of the LL-37-Derived Peptide Fragment KR12-Structural Analysis, Surface-Active Properties and Antimicrobial Activity. Int. J. Mol. Sci. 2020, 21, 887. [CrossRef] [PubMed]

89. Ding, B.; Soblosky, L.; Nguyen, K.; Geng, J.; Yu, X.; Ramamoorthy, A.; Chen, Z. Physiologically-relevant modes of membrane interactions by the human antimicrobial peptide, LL-37, revealed by SFG experiments. Sci. Rep. 2013, 3, 1854. [CrossRef] [PubMed]

90. Hallock, K.J.; Lee, D.K.; Ramamoorthy, A. MSI-78, an analogue of the magainin antimicrobial peptides, disrupts lipid bilayer structure via positive curvature strain. Biophys. J. 2003, 84, 3052-3060. [CrossRef]

91. Nguyen, F.; Starosta, A.L.; Arenz, S.; Sohmen, D.; Donhofer, A.; Wilson, D.N. Tetracycline antibiotics and resistance mechanisms. Biol. Chem. 2014, 395, 559-575. [CrossRef]

92. Lohner, K. Membrane-active Antimicrobial Peptides as Template Structures for Novel Antibiotic Agents. Curr. Top. Med. Chem. 2017, 17, 508-519. [CrossRef]

93. Rodríguez-Rojas, A.; Moreno-Morales, J.; Mason, A.J.; Rolff, J. Cationic antimicrobial peptides do not change recombination frequency in Escherichia coli. Biol. Lett. 2018, 14, 20180006. [CrossRef]

94. FDA. The Drug Development Process. Available online: https://www.fda.gov/patients/learn-about-druganddevice-approvals/drug-development-process (accessed on 30 April 2020). 
95. Muller, P.Y.; Milton, M.N. The determination and interpretation of the therapeutic index in drug development. Nat. Rev. Drug Discov. 2012, 11, 751-761. [CrossRef]

96. Miyazaki, Y.; Aoki, M.; Yano, Y.; Matsuzaki, K. Interaction of antimicrobial peptide magainin 2 with gangliosides as a target for human cell binding. Biochemistry 2012, 51, 10229-10235. [CrossRef]

97. Epand, R.F.; Maloy, W.L.; Ramamoorthy, A.; Epand, R.M. Probing the "charge cluster mechanism" in amphipathic helical cationic antimicrobial peptides. Biochemistry 2010, 49, 4076-4084. [CrossRef]

98. Epand, R.F.; Maloy, L.; Ramamoorthy, A.; Epand, R.M. Amphipathic helical cationic antimicrobial peptides promote rapid formation of crystalline states in the presence of phosphatidylglycerol: Lipid clustering in anionic membranes. Biophys. J. 2010, 98, 2564-2573. [CrossRef] [PubMed]

C 2020 by the authors. Licensee MDPI, Basel, Switzerland. This article is an open access article distributed under the terms and conditions of the Creative Commons Attribution (CC BY) license (http://creativecommons.org/licenses/by/4.0/). 